\title{
The Role of PET-CT in the Differential Diagnosis of Malignant-Paramalignant Pleural Effusion
}

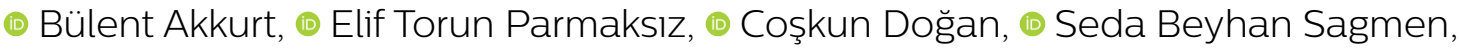

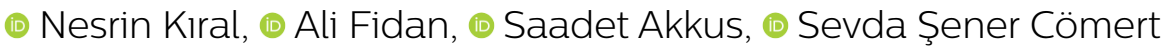

Department of Chest Diseases, University of Health Sciences, Kartal Dr. Lütfi Kırdar Training and Research Hospital, İstanbul, Turkey

Submitted: 15.04.2019 Accepted: 21.05.2019

Correspondence: Bülent Akkurt, Kartal Dr. Lütfi Kırdar Eğitim ve Araştırma Hastanesi, Göğüs Hastalıkları Kliniği, İstanbul, Turkey E-mail: bulentakkurt@hotmail.com.tr

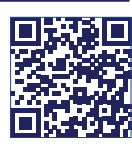

Keywords: Malignant pleural effusion; paramalignant pleural effusion; PET-CT.

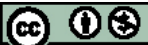

This work is licensed d dera create This work is licensed under a Creative Commons
Attribution-NonCommercial 4.0 International License.

\begin{abstract}
Objective: Pleural effusion is an important problem in cancer patients as it will affect the stage, prognosis and treatment. Therefore, it is necessary to distinguish between paramalignant and malignant effusions. In this study, we aimed to investigate the role of PET-CT in the evaluation of pleural effusion.
\end{abstract}

Methods: Patients diagnosed with malignancy and associated pleural effusion and evaluated by PET-CT were prospectively included in this study. SUDmax values of pleural fluid were recorded in consideration of the demographic information and PET-CT findings. In all patients, biochemical parameters, including glucose, $\mathrm{LDH}$, albumin and total protein and $\mathrm{pH}$ values of the pleural fluid obtained by thoracentesis, were measured. All pleural fluid samples were sent for cytological evaluation. After cytological evaluation, patients were defined as having malignant or paramalignant pleural effusion and accordingly divided into two groups. The t-test was used to compare SUDmax values between the groups. A chi-square test was used to compare categorical data.

Results: A total of 69 patients (30 women [43\%] and 39 men [57\%]) with a mean age of 63.55 (37-88) years were included in this study. The cytological analysis revealed malignant pleural effusion in 53 patients. In the follow-up of 16 patients, pleural fluid was accepted as of paramalignant nature due to the absence of both atypical cells in the fluid cytology and also clinical findings favoring malignancy. The mean SUDmax value was found to be I.43 in paramalignant fluids and 1.5 in malignant fluids but without any statistically significant difference. Malignant cytological findings were detected despite the absence of FDG involvement in 23 (33\%) cases, including patients with lung cancer $(n=13)$, mesothelioma $(n=3)$, breast cancer $(n=2)$, colon cancer $(n=2)$, ovarian cancer $(n=1)$, gastric cancer $(n=1)$, or endometrial cancer $(n=1)$. PET had a sensitivity of $56.6 \%$ and a specificity of $50 \%$ in the detection of malignant pleural effusions with a $78.9 \%$ positive, and $25.8 \%$ negative predictive value.

Conclusion: Distinguishing between malignant and paramalignant effusions according to FDG uptake in pleural fluids may cause misleading results. Therefore, we suggest that advanced diagnostic procedures should be used in cases where the presence of malignant fluid will change the clinical approach.

\section{INTRODUCTION}

Pleural effusion is one of the most common thoracic pathologies. Congestive heart failure, pneumonia, malignancies, pulmonary embolism and viral infections account for $90 \%$ of the pleural effusions. ${ }^{[1]}$ In the diagnosis of pleural effusions, the first step examination is usually thoracentesis. However, thoracentesis does not have sufficient diagnostic efficacy in many cases with exudative pleural effusion. Therefore, additional investigations are needed. Positron emission tomography/computed tomography
(PET/CT), which is one of the noninvasive methods in the diagnosis of pleural effusion, is an imaging method used to differentiate between malignant and paramalignant effusions in pleural diseases. ${ }^{[2]}$ In cases with suspected pleural malignancy, PET/CT has a sensitivity of $83-100 \%$ and a specificity of $67-94 \%$. The mean sensitivity and specificity were found to be around $86 \%$ and $80 \%$ in the differentiation of pleural metastasis in patients with lung cancer, respectively. ${ }^{[3]}$ The unilateral or bilateral fluid accumulation may occur in the thorax during the course of malignant diseases. These fluids are named in two ways: ${ }^{[4]}$ 
I. Malignant pleural effusion (MPE): Cytological evaluation of pleural fluid or parietal pleural biopsy detects malignant cells.

2. Paramalignant pleural effusion: It is fluid accumulation due to secondary causes, such as bronchial obstruction, obstruction of lymphatics, or pulmonary embolism. Their cytological evaluation does not reveal malignant cells.

Pleural effusion is an important problem in cancer patients because its occurrence may affect stage, prognosis and treatment. Therefore, it is necessary to distinguish between paramalignant and malignant effusions. In this study, we aimed to investigate the role of PET-CT in the evaluation of malignant and paramalignant pleural effusions in patients with known malignancy.

\section{MATERIALS AND METHODS}

\section{Patients}

Between July 2017 and August 2018, patients with a diagnosis of malignancy and associated pleural effusion who were evaluated by PET-CT were prospectively included in this study. SUDmax values of pleural fluid samples were recorded in consideration of the demographic information and PET-CT findings of the patients. Consent forms were obtained from all patients. All patients underwent thoracentesis with the aid of thorax ultrasonography (USG) to measure biochemical parameters of the pleural fluids, including glucose, lactate dehydrogenase (LDH), albumin, and total protein. Serum values of the same parameters were measured simultaneously.

All pleural effusion samples were sent for cytological evaluation. If the atypical cell was detected in fluid cytology, it was evaluated as malignant pleural fluid. Pleural fluid was accepted as paramalignant if any atypical cell was not detected in pleural fluid during fluid cytology and recurrent thoracenteses, and in the presence of other etiologies to explain fluid formation (such as pneumonia, atelectasis, hypoalbuminemia) associated with the absence of clinical findings in favor of malignancy.

\section{Procedures}

In our study, GE Logic 7 US device (General Electric medical system, logic 7 expert ultrasound machine (Sony Corporation, Japan) and $3.5 \mathrm{MHz}$ convex probe were used for thoracic US imaging. PET-CT scan and TF TOF were performed from the beginning to the pelvic floor with PET / CT device (Philips, Cleveland, Ohio, USA). The injected I8F-FDG ranged from 350 to $450 \mathrm{MBq}$, depending on the weight of the patient. The cross-sectional thickness of 5 $\mathrm{mm}$ was obtained with 50-120 mAS and 90-140 kV PET images were obtained using the $3 \mathrm{D}$ model in the same scanning range as $\mathrm{CT}$.

\section{Statistical analysis}

Statistical analyses were performed using SPSS 17.0 program. Data were recorded as mean \pm standard deviation. The t-test was used to compare SUDmax values between the groups. The chi-square test was used to compare categorical data. Pearson correlation test was used for correlation analysis of parametric data. P-value of less than 0.05 was considered statistically significant.

\section{RESULTS}

A total of 69 patients (30 female, $43 \%$, and 39 male: $57 \%$ ) with a mean age of $63.55(37-88)$ years were included in this study. The most common tumor type was lung cancer $(n=28,41 \%)$, followed by breast cancer $(n=13,19 \%)$ and mesothelioma $(n=8,12 \%)$. Other malignancies were ovarian cancer, colon cancer, gastric cancer, bladder cancer, lymphoma, cervical cancer, soft tissue tumor, Ewing's sarcoma, uterine cancer and rectum cancer.

The cytological analysis revealed malignant pleural effusion in $53(77 \%)$ of the patients; the presence of paramalignant pleural effusion was considered in $16(23 \%)$ patients due to the absence of both atypical cells in fluid cytology and also clinical findings favoring malignancy.

Biochemical and SUDmax values in paramalignant and malignant fluids are shown in Table I. Among biochemical parameters, LDH and LDH ratios were found to be sta-

Table I. Biochemical values of pleural fluids, and SUDmax values

\begin{tabular}{lccc}
\hline & Paramalignant effusion & Malignant effusion & p-value \\
\hline $\mathrm{n}$ & 16 & 53 & 0.07 \\
Pleural fluid protein $(\mathrm{mg} / \mathrm{dL})$ & 3.85 & 4.28 & 0.06 \\
Pleural fluid albumin $(\mathrm{mg} / \mathrm{dL})$ & 2.13 & 2.49 & $<0.001$ \\
Pleural fluid lactate dehydrogenase (U/L) & 219 & 563 & 0.015 \\
Fluid glukoz (mg/dL) & 135 & 106 & 0.05 \\
Fluid pH & 7.42 & 7.37 & 0.003 \\
LDH ratio & 1.01 & 1.99 & 0.004 \\
Protein ratio & 0.55 & 0.67 & 0.004 \\
Albumin gradient $(\mathrm{mg} / \mathrm{dL})$ & 1.46 & 0.92 & 0.89 \\
Fluid SUDmax & 1.43 & 1.5 & \\
\hline
\end{tabular}


Table 2. Biochemical values of pleural fluids according to tumor types

\begin{tabular}{|c|c|c|c|c|c|c|c|c|}
\hline $\begin{array}{l}\text { Type of } \\
\text { malignancy }\end{array}$ & $\begin{array}{c}\text { Pleural } \\
\text { fluid } \\
\text { protein } \\
\text { (mg/dL) }\end{array}$ & $\begin{array}{l}\text { Pleural } \\
\text { fluid } \\
\text { albumin } \\
\text { (mg/dL) }\end{array}$ & $\begin{array}{l}\text { Pleural } \\
\text { fluid } \\
\text { LDH } \\
\text { (U/L) }\end{array}$ & $\begin{array}{l}\text { Pleural } \\
\text { fluid } \\
\text { glucose } \\
\text { (mg/dL) }\end{array}$ & $\begin{array}{c}\text { Pleural } \\
\text { fluid } \\
\text { pH }\end{array}$ & $\begin{array}{l}\text { Pleural } \\
\text { fluid } \\
\text { LDH } \\
\text { ratio }\end{array}$ & $\begin{array}{l}\text { Pleural } \\
\text { fluid } \\
\text { protein } \\
\text { ratio }\end{array}$ & $\begin{array}{l}\text { Pleural fluid } \\
\text { albumin } \\
\text { gradient } \\
\text { (mg/dL) }\end{array}$ \\
\hline Lung & 4 & 2.25 & 549 & 112 & 7.36 & 1.88 & 0.65 & 1.18 \\
\hline Breast & 4.35 & 2.69 & 413 & 123 & 7.41 & 1.39 & 0.64 & 1.01 \\
\hline Mesothelioma & 4.81 & 2.81 & 420 & 102 & 7.34 & 2.29 & 0.69 & 0.72 \\
\hline Ovary & 3.88 & 2.21 & 267 & 100 & 7.42 & 1.07 & 0.58 & 0.8 \\
\hline Colon & 4.14 & 2.38 & 835 & 87 & 7.33 & 2.71 & 0.62 & 1.05 \\
\hline Stomach & 4.56 & 2.52 & 386 & 96 & 7.67 & 1.91 & 0.65 & 1.04 \\
\hline Bladder & 4.33 & 2.51 & 522 & 190 & 7.27 & 1.89 & 0.71 & 0.65 \\
\hline Lymphoma & 2.92 & 1.13 & 440 & 124 & 7.47 & 0.78 & 0.45 & 2.01 \\
\hline Cervix & 3.65 & 2.06 & 887 & 58 & 7.3 & 0.93 & 0.59 & 0.94 \\
\hline Soft tissue & 5.08 & 3.08 & 302 & 86 & 7.37 & 1.80 & 0.73 & 0.92 \\
\hline Ewing's sarcoma & 4.02 & 2.68 & 238 & 102 & 7.56 & 1.17 & 0.6 & 1.32 \\
\hline Uterus & 4.95 & 2.81 & 431 & 101 & 7.38 & 2.5 & 0.69 & 0.29 \\
\hline Rectum & 3.11 & I.77" & 202 & 138 & 7.50 & 0.73 & 0.43 & 1.63 \\
\hline
\end{tabular}

LDH: Lactate dehydrogenase.

Table 3. Distribution of SUDmax values according to tumor types

\begin{tabular}{lccc}
\hline $\begin{array}{l}\text { Type of } \\
\text { malignancy }\end{array}$ & (n) & $\begin{array}{c}\text { SUDmax } \\
\text { (median) }\end{array}$ & $\begin{array}{c}\text { Malignant/ } \\
\text { paramalignant } \\
\text { (n-\%) }\end{array}$ \\
\hline Lung & 28 & $1.25(0-9)$ & $20 / 8-71.4 \%$ \\
Breast & 13 & $2.18(0-4.78)$ & $11 / 2-84.6 \%$ \\
Mesothelioma & 8 & $1.27(0-3.1)$ & $8 / 0-100 \%$ \\
Ovary & 4 & $1.77(0-2.5)$ & $3 / 1-75 \%$ \\
Colon & 3 & 0 & $2 / 1-66.7 \%$ \\
Stomach & 3 & $1.23(0-2)$ & $2 / 1-66.7 \%$ \\
Bladder & 3 & $3.63(1.8-5.8)$ & $3 / 0-100 \%$ \\
Lymphoma & 2 & $1.25(1-1.5)$ & $1 / 1-50 \%$ \\
Cervix & 1 & 2 & $1 / 0-100 \%$ \\
Soft tissue & 1 & 0 & 0 \\
Ewing's sarcoma & 1 & 2.8 & $1 / 0-100 \%$ \\
Uterus & 1 & 0 & $1 / 0-100 \%$ \\
Rectum & 1 & 0 & $1 / 0-100 \%$ \\
\hline
\end{tabular}

tistically significantly higher in the group with malignant pleural effusions $(p<0.001, p=0.003$, respectively). Pleural fluid glucose levels were also lower in the malignant pleural effusion group $(p=0.015)$. The protein ratio was higher in the malignant pleural effusion group $(p=0.004)$. Albumin gradient was higher in the paramalignant pleural effusion group as expected $(p=0.004)$.

The distribution of the mean values of biochemical parameters according to tumor types is shown in Table 2. Mean SUDmax values for tumor types are shown in Table 3.

The mean SUDmax values were found to be 1.43 in paramalignant, and 1.5 in malignant effusions without any statistically significant intergroup difference. Correlation tests showed positive correlation between FDG uptake and pleural fluid albumin $(r=0.147)$, protein $(r=0.156)$ and LDH $(r=0.052)$ but negative correlation with pleural fluid $\mathrm{pH}$ values $(\mathrm{r}=-0.07)$. However, these correlations were not statistically significant $(p=0.22 ; 0.19 ; 0.67 ; 0.55$, respectively). Malignant cytologic findings were detected in 23 (33\%) cases, without any FDG uptake, including patients with lung cancer $(n=13)$, mesothelioma $(n=3)$, breast cancer $(n=2)$, colon cancer $(n=2)$, ovarian cancer $(n=1)$, gastric cancer $(n=l)$, and endometrial cancer $(n=l)$.

According to our results, the sensitivity and specificity of PET for detecting malignant pleural fluids were $56.6 \%$ and $50 \%$, respectively, with a positive predictive value of $78.9 \%$ and a negative predictive value of $25.8 \%$.

\section{DISCUSSION}

In our study, no significant difference was found between the paramalignant and malignant effusions concerning PET/ CT SUDmax values. PET-CT had a sensitivity and specificity of $56.6 \%$ and $50 \%$ for malignant pleural effusions, respectively, with positive and negative predictive values of $78.9 \%$ and $25.8 \%$. The majority of the patients included in this study consisted of lung cancer, breast cancer and mesothelioma patients.

In our study, biochemical parameters and PET/CT SUDmax values in the pleural fluid were compared and it was observed that SUDmax values increased when protein, albumin and LDH levels increased and decreased when $\mathrm{pH}$ increased. However, this correlation was not statistically significant.

One of the similar studies evaluating the diagnostic efficacy of PET/CT in the pleural fluid was conducted by Duysinx et al. ${ }^{[5]}$ Seventy-nine patients were included in this 
study that investigated the diagnostic efficacy of PET/CT in exudative pleural effusions.

The patients were divided into two groups as having malignant $(n=5 \mathrm{I}, 65 \%)$ and paramalignant pleural effusions $(n=35)$ and PET/CT involvement were found to be higher in malignant effusions with a significant intergroup difference $(p<0.00 I)$. In this study, the SUDmax limit value was determined as 2.2. In our study, no significant difference was found between the two groups and any limit value could not be determined. In the study conducted by Yildirim et al. ${ }^{[6]}$ on 31 patients, the utility of PET/CT in the differentiation of malignant mesothelioma and asbestos-associated pleural diseases was investigated. In this study, the SUDmax value was determined as 6.5. In our study, eight patients received the diagnosis of malignant mesothelioma and the average SUDmax value was measured as I.27.

Thirty-three patients were included in the study conducted by Liao et al., ${ }^{[7]}$ and 27 (82\%) patients were followed-up with malignant pleural effusion and 6 (18\%) with benign pleural effusion. PET-CT was found to be effective in detecting malignant pleural effusions $(p<0.05)$.

The researchers reported that PET-CT had a sensitivity of $81.5 \%$, a specificity of $83.3 \%$, a positive predictive value of $95.7 \%$, and a negative predictive value of $50.0 \%$. In our study, the sensitivity and specificity of PET-CT for malignant pleural fluids were found to be $56.6 \%$ and $50 \%$, respectively, with a positive predictive value of $78.9 \%$ and a negative predictive value of $25.8 \%$.

In the study conducted by Nakajima et al., ${ }^{[8]}$ the efficacy of PET/CT was evaluated in the differential diagnosis of malignant pleural effusions. In this study with 36 patients, PET/CT was found to be significantly helpful in the diagnosis of malignant pleural effusion $(p<0.05)$. In a study conducted by Sun et al.," ${ }^{[9]} 176$ patients were included in the study and the efficacy of PET/CT in the differential diagnosis of malignant and paramalignant pleural effusions were investigated.

In this study, $108(61 \%)$ patients were diagnosed as having malignant, and 68 (39\%) patients as paramalignant pleural effusionsand PET/CT involvement was found to be higher in malignant effusions with a significant intergroup difference $(p<0.001)$.

Thirty-three patients with pleural effusion who were diagnosed with lung cancer were included in a study conducted by Kim et al. ${ }^{\left[{ }^{10]}\right.}$ In this study, the efficacy of PET-CT in detecting malignant pleural effusions was evaluated in 24 (73\%) patients with malignant pleural effusions and 9 (27\%) patients with pleural effusions due to benign causes. SUDmax values on PET-CT were detected to be higher in patients with malignant pleural effusion $(p<0.05)$. Also, in this study, when the CT images were evaluated, the positive radiological findings in the malignant pleural effusion group were present in 20 (83\%) of the 24 patients, whereas only I (I I\%) of the 9 patients in the benign group had positive radiological findings $(p<0.00 \mathrm{I})$.
In the study conducted by Letovanec et al.,[ ${ }^{[1]} 47$ patients with known malignancşes were included, and PET-CT findings of these patients were compared. Patients were divided into two groups as patients having malignant or paramalignant pleural effusions after cytological examination according to causes of pleural effusion. Seventeen (36\%) patients had malignant pleural effusion, and 30 (64\%) had paramalignant pleural effusion. As a result of the study, the SUDmax values measured on PET-CT were found to be significantly higher in the malignant effusion group $(\mathrm{p}=0.00 \mathrm{I})$.

In our study, the diagnosis of paramalignant pleural effusion was based on pleural fluid cytology results and clinical and radiological follow-up findings and no further invasive intervention was performed. This may be considered a limitation of our study. In addition, conducting the study in a single-center, the small number of patients and the fact that the number of patients was not homogeneously distributed among the groups can be considered as other limitations of the study.

\section{CONCLUSION}

In conclusion, differentiating between malignant and paramalignant pleural effusions according to FDG involvement may lead to misleading results. Therefore, we suggest that advanced diagnostic procedures should be used in cases where the presence of malignant fluid will change the clinical approach. The unicentric conduction of our study, the low number of patients and that the number of patients was not distributed homogenously were significant limitations. We believe that large-scale studies should be conducted with a higher number of patients.

\section{Informed Consent}

Prospective study.

Peer-review

Internally peer-reviewed.

Authorship Contributions

Concept: E.T.P.; Design: E.T.P., S.Ş.C.; Supervision: S.Ş.C.; Fundings: B.A.; Materials: B.A.; Data: B.A., S.A.; Analysis: A.F., C.D.; Literature search: N.G.K., S.B.S.; Writing: B.A.; Critical revision: S.Ş.C., E.T.P.

Conflict of Interest

None declared.

\section{REFERENCES}

1. Chinchkar NJ, Talwar D, Jain SK. A stepwise approach to the etiologic diagnosis of pleural effusion in respiratory intensive care unit and short-term evaluation of treatment. Lung India 2015;32:10715. [CrossRef]

2. Lee P, Mathur PN. Advances in pleural diseases: what is the future for medical thoracoscopy? Curr Opin Pulm Med 2016;22:297-308.

3. Treglia G, Sadeghi R, Annunziata S, Lococo F, Cafarotti S, Prior JO, et al. Diagnostic performance of fluorine-18-fluorodeoxyglucose positron emission tomography in the assessment of pleural abnormalities 
in cancer patients: a systematic review and a meta-analysis. Lung Cancer 2014;83:1-7. [CrossRef]

4. Azzopardi M, Porcel MJ, Lee YC, Fysh ET, Koegelenberg CF. Current controversies in the management of malignant pleural effusions. Semin Respir Crit Care Med 2014;35:723-31. [CrossRef]

5. Duysinx BC, Larock MP, Nguyen D, Corhay JL, Bury T, Hustinx R, et al. 18F-FDG PET imaging in assessing exudative pleural effusions. Nucl Med Commun 2006;27:971-6. [CrossRef]

6. Yildirim H, Metintas M, Entok E, Ak G, Ak I, Dundar E, et al. Clinical value of fluorodeoxyglucose-positron emission tomography/computed tomography in differentiation of malignant mesothelioma from asbestos-related benign pleural disease: an observational pilot study. J Thorac Oncol 2009;4:1480-4. [CrossRef]

7. Liao R, Yang X, Wang S, Zhou Q, Nie Q, Zhong W, et al. Clinical role of F-18 FDG PET/CT in differentiating malignant and benign pleural effusion in patients with lung cancer. Zhongguo Fei Ai Za Zhi 2012;15:652-5.

8. Nakajima R, Abe K, Sakai S. Diagnostic Ability of FDG-PET/CT in the Detection of Malignant Pleural Effusion. Medicine (Baltimore) 2015;94:e1010. [CrossRef]

9. Sun Y, Yu H, Ma J, Lu P. The role of 18F-FDG PET/CT integrated imaging in distinguishing malignant from benign pleural effusion. PloS One 2016;11:e161764. [CrossRef]

10. Kim BS, Kim IJ, Kim SJ, Pak K, Kim K. Predictive value of F-18 FDG PET/CT for malignant pleural effusion in non-small cell lung cancer patients. Onkologie 2011;34:298-303. [CrossRef]

11. Letovanec I, Allenbach G, Mihaescu A, Nicod Lalonde M, Schmidt $\mathrm{S}$, Stupp R, et al. ${ }^{18} \mathrm{~F}$-fluorodeoxyglucose PET/CT findings in pleural effusions of patients with known cancer. A cytopathological correlation. Nuklearmedizin 2012;51:186-93. [CrossRef]

\section{Malign-Paramalign Plevral Sıvının Ayırıcı Tanısında PET-BT'nin rolü}

Amaç: Kanser hastalarında plevral efüzyon görülmesi evreyi, prognozu ve tedaviyi etkileyeceği için önemli bir sorundur. Bu nedenle paramalign-malign sıvı ayrımının yapılması gereklidir. Çalışmamızda PET-BT'nin plevral efüzyonu değerlendirmedeki rolünü araştırmayı amaçladık.

Gereç ve Yöntem: Malignite tanısı ve eşlik eden plevral efüzyonu olup, PET-BT ile değerlendirilen hastalar ileriye yönelik olarak çalışmaya alındı. Hastaların demografik bilgileri ve PET-BT bulgularına göre plevral sıvının SUDmaks değerleri kaydedildi. Tüm hastalarda torasentez yapılarak plevral sıvının glukoz, LDH, albumin ve total protein içeren biyokimyasal parametleri ölçüldü, pH değerleri bakıldı. Tüm plevral sıvılar sitolojik değerlendirme için gönderildi. Sitolojik değerlendirme sonrasında hastalar malign veya paramalign plevral efüzyon olarak tanımlandı ve iki gruba ayrıldı. Gruplar arasında SUDmax değerlerinin karşılaştırılmasında t-testi kullanıldı. Kategorik verilerin karşılaştııılmasında ise ki-kare testi kullanıldı.

Bulgular: Çalışmaya yaş ortalaması 63.55 (37-88) yıl olan 30 kadın (\%43), 39 erkek (\%57) toplam 69 hasta alındı. Sitolojik analiz ile 53 hastada malign plevral efüzyon saptandı; 16 hastanın takiplerinde sıvı sitolojisinde atipik hücre saptanmaması ve malignite lehine klinik bulgu gelişmemesi nedeniyle plevral sıvı paramalign olarak kabul edildi. Paramalign sıvılarda ortalama SUDmaks I.43, malign sıvılarda I.5 olarak bulundu, aralarında anlamlı fark saptanmadı. Akciğer kanseri olan 13, mezotelyoma olan 3, meme kanseri olan 2, kolon kanseri olan 2, over kanseri olan I, mide kanseri olan I ve endometrium kanseri olan I olgu olmak üzere toplam 23 (\%33) olguda FDG tutulumu olmadığı halde malign sitolojik bulgular saptandı. PET'nin malign plevral sıvıları saptamak için sensitivitesi \%56.6, spesifisitesi \%50 bulundu; pozitif prediktif değeri \%78.9, negatif prediktif değeri \%25.8 olarak hesaplandı.

Sonuç: Plevral sıvılarda FDG tutulumuna göre malign-paramalign ayrımı yapmak yanıltıcı sonuçlara neden olabilir. Bu nedenle, malign sıvı varlı̆ının klinik yaklaşımı değiştireceği olgularda ileri tanısal işlemlerin kullanılması gerektiğini öne sürüyoruz.

Anahtar Sözcükler: Malign plevral efüzyon; paramalign plevral efüzyon; PET-BT. 